DOI: $10.12957 /$ concinnitas.2019.44888

\title{
SIMBOLISMOS DA DESOBEDIÊNCIA NO FILME ASCENSÃO E QUEDA DAS BIXAS: O ESTADO ENTICO E A QUEDA DISRPUTIVA
}

\author{
Rodrigo D’Alcântara ${ }^{1}$
}

\begin{abstract}
Resumo: Este artigo é um recorte dos conceitos de "estado entico performático" e "queda disruptiva" trabalhados em minha dissertação de mestrado intitulada "O desejo por trás da queda: Ficções e ritos do corpo bixa"(PPGAV/UFRJ, 2018). 0 filme video-artístico Ascensão e Queda das Bixas (2018), o qual assino a direção, permeia todo o texto colocando as personagens em diálogo com tais conceitos. As fantasias e ficções contra- hegemônicas e anti-coloniais são aqui expostas como forma de resistência dissidente dentro dessa investigação que parte da linguagem audiovisual experimental da video- arte.
\end{abstract}

Palavras-chave: LGBT; Audiovisual; Arte Contemporânea; Simbolismos; Sagrado.

\section{Disobedience symbolisms in the movie Ascension and Fall of the Bixas:}

\section{The entity state and the disruptive fall}

\begin{abstract}
This article is a fragment of the concepts of "entity performance state" and "disruptive fall" which were developed during my master's dissertation titled "The Desire Behind Fall: Fictions and Rites of the Bixa Body" (PPGAV / UFRJ, 2018). The video-artistic fim Ascension and Fall of the Bixas (2018), directed by me, permeates the whole text placing the characters in dialogue with such concepts. Antihegemonic and anti-colonial fantasies and fictions are here exposed as a form of dissident resistance within this research that starts from the experimental audiovisual language of video art.
\end{abstract}

Key-words: LGBT; Audiovisual; Contemporary Art; Symbolism; Sacred.

\footnotetext{
${ }^{1}$ Rodrigo de Alcântara Barros Bueno. Mestre pelo Programa de Pós-Graduação em Artes Visuais da Universidade Federal do Rio de Janeiro, com bolsa CNPq na linha de pesquisa Poéticas Interdisciplinares. Graduado em Artes Plásticas pela Universidade de Brasília.
} 


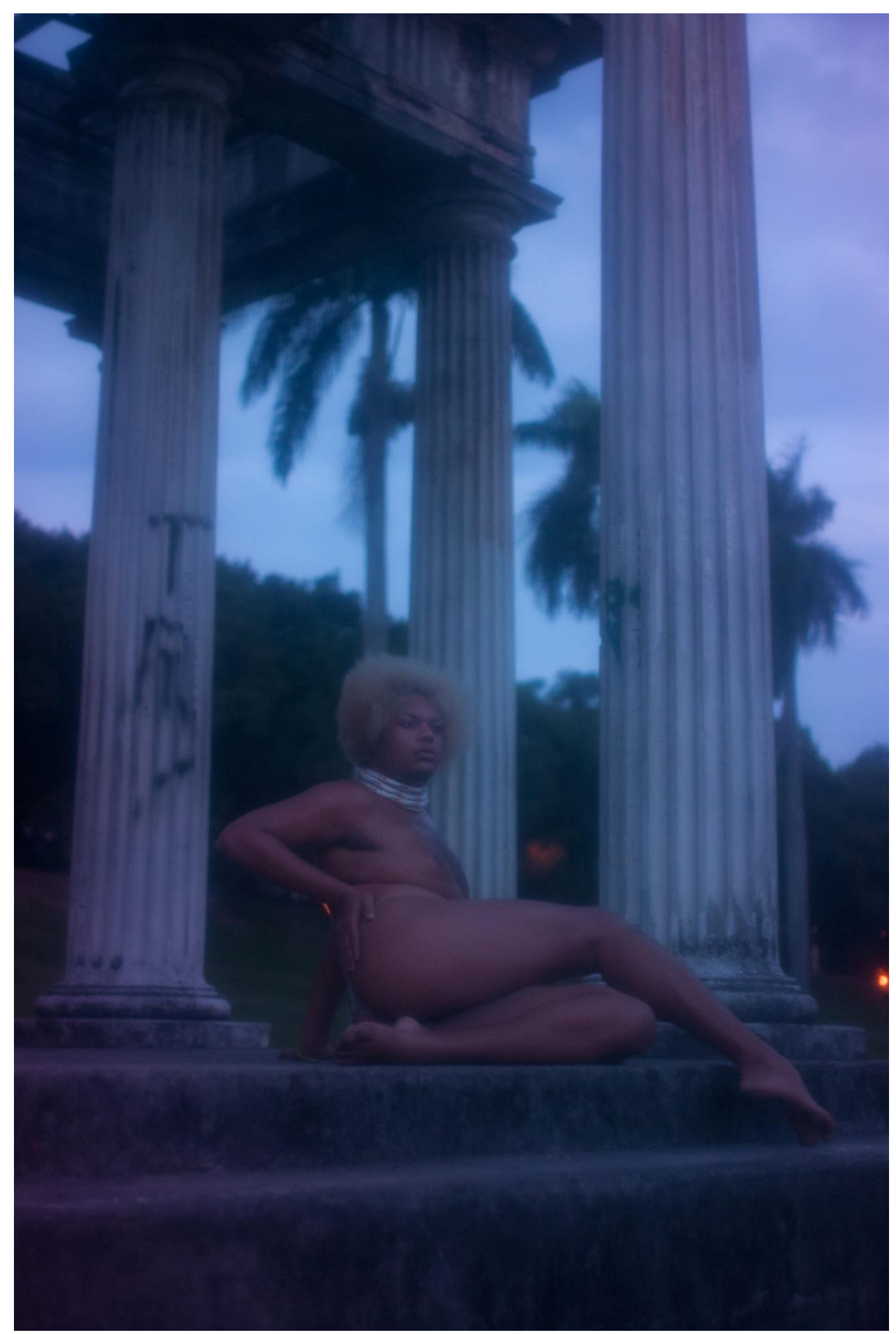

Imagem 1: Ventura Profana como "Arauta, a primeira mensageira" durante prólogo do Passo I. Ascensão e Queda das Bixas. Direção Rodrigo D’Alcântara. 38'. 2018. Still: Salomão. 


\section{Construindo Fantasias Contra-Hegemônicas no Presente}

Este texto foi escrito em consonância com o momento presente e suas particularidades políticas, a partir da minha perspectiva subjetiva de artista brasileiro dissidente. Partirei do pressuposto que o presente contemporâneo é composto pela coexistência de realidades distópicas e utópicas. Assim sendo, essas duas realidades são inscritas por nossas sociedades dependendo de diversas variantes sociais e culturais, conforme escolhemos ou somos submetidxs/impostxs, a formas ficcionais de aceitar o que é real. As noções de passado, presente e futuro têm se confundido enquanto vivemos em um momento hauntológico $^{2}$, no qual a expectativa de futuro não pode mais ser projetada ou idealizada. Nós só temos o presente ou o retorno ao passado; algo intensificado ao pensarmos que hoje somos assombradxs por discursos de retrocesso que tomam o presente e instalam-se paulatinamente sobre a frágil democracia brasileira. Vivemos várias realidades paralelas no Brasil e no mundo, onde as fantasias coloniais prevalecem como principal ficção operante. À medida que a civilização mostra sinais de colapso mundialmente, é urgente repensar os papéis e padrões que perpetuamos na academia e no meio artístico que seguem um hétero cis-tema ${ }^{3}$ corrosivo coligado ao colonialismo e as suas noções predatórias de sagrado. Durante minha trajetória interpolada por pesquisa e criação artística, através de um ângulo dissidente, pude tomar consciência sobre minhas escolhas de composições baseadas em ficções, simbolismos e questionamentos do que percebemos como realidade. A perspectiva dissidente na criação artística é uma possibilidade urgente para a transformação das fantasias coloniais e subsequentemente para a compreensão dos caminhos simbólicos construídos historicamente responsáveis pelas realidades utópicas e distópicas que nos cercam.

\footnotetext{
2 FISHER, 2009. "Assombração" é uma leitura possível do conceito cunhado por Fisher.

${ }^{3}$ Abreviação para sistema cisgênero e heterossexual. 0 termo cisgênero vem sendo cunhado por pensadorxs LGBTs, principalmente trans e travestis, para nomear aqueles que a identidade de gênero está de acordo com a identidade biológica binária (homem/mulher).
} 


\begin{abstract}
“Opondo-se a essa consequência histórica do colonialismo, reivindicamos a noção de fantasia como uma força política do até agora inimaginável e do que é possível imaginar. Nossa capacidade de transformar a sociedade depende da nossa capacidade de imaginar uma realidade diferente". (CACERES; MESQUITA; UTIKAL. 2017. p.10 - tradução livre)
\end{abstract}

Com a vontade de propor um novo imaginário provindo de fantasias contrahegemônicas escrevi minha dissertação de mestrado na Universidade Federal do Rio de Janeiro (2016 - 2018) intitulada O desejo por trás da queda: Ficções e ritos do corpo bixa, ponto de partida para os pensamentos que compõem este texto. $\mathrm{Na}$ primeira parte da pesquisa de mestrado proponho um modo ficcional metafórico operante em nossa civilização ocidental cujo centro seria um núcleo hétero cistemico hegemônico no qual as vivências dissidentes são então lançadxs a orbitar às margens. A partir daí penso que haja uma relação de sideração ${ }^{4}$ entre o núcleo e a margem para entender poeticamente o lugar da queda iminente dos corpos dissidentes. Os corpos dissidentes são almejados e alvejados pelos olhares siderantes daqueles que habitam o núcleo normativo. Ao decorrer da pesquisa do mestrado procurei diálogos entre corpos em queda e seus simbolismos, entendendo o corpo dissidente como protagonista dessa lógica ficcional. Os ícones sagrados ocidentais que transmitem a ideia da queda por um viés homoerótico são então abordados como início de minha investigação artística de subversão. Temas como o êxtase, o desfalecimento, o corpo perfurado e andrógino de São Sebastião, a queda disruptiva de Ícaro, entre outros, guiaram a primeira fase dessa investigação. Sigo esse ínterim buscando um caminho possível para o corpo dissidente e a queda, que se desdobra entre santos e anti-atletas, sóis e cucetas, entidades e corpos. A exploração desses temas culminou na realização da principal obra visual do meu período de mestrado, o filme video-artístico Ascensão e Queda das Bixas ${ }^{5}$ (Estilizado como AQ das Bixas. 38 '. 2018) o qual escrevi, dirigi e produzi.

\footnotetext{
4 "A sideração é o afeto inevitável de todo pensamento que enfrenta a existência de uma exterioridade, de um fora inevitavelmente perturbador" . MONDZAIN, 2016. p.13.

5 Trailer do filme: https://vimeo.com/273013515. A obra teve sua pré-estreia na Galeria Z42 (28/07/18,RJ), estreia nacional no Espaço cultural Despina (08/08/18, RJ) e estreia internacional no Transformations Trans Film Festival (30/11/18, Berlim, DE)
} 
Ascensão e Queda dos Bixas é uma produção brasileira independente ${ }^{6}$ construída em colaboração com diversxs artistas da América Latina. 0 filme é um esforço coletivo composto por artistas dissidentes de diferentes estados brasileiros e países como Chile, Colômbia e Equador. A trama acontece em um futuro distópico no qual entidades dissidentes surgem após eras de domínio endêmico do regime heterossexual. 0 filme é uma experiência estética e sonora, sendo estruturado em três capítulos guiados por uma atmosfera mitológica com influências futurísticas, pós-pornográficas e neobarrocas; tendo sido também fortemente influenciado por álbuns visuais, detalhes que me debruçarei ao decorrer dos próximos tópicos.

Durante a realização deste filme tive que assumir múltiplas tarefas diante da precariedade dos recursos culturais e da falta de incentivos suficientes para sua realização, já fruto do desmonte e descaso com a cultura e os saberes LGBTs. Desta forma precisei lidar ainda mais com a urgência do presente esmagador no Brasil, que já é um projeto de distopia desde sua fundação como terra colonizada. 0 pensamento colonial define desde sua base predatória quem é civilizado e nãocivilizado $^{7}$. No Brasil habitamos um território que nunca deixou de ser colônia. Ascensão e Queda das Bixas apresenta-se como uma ficção narrada em um futuro distópico, sendo então uma representação artística metafórica da sobrevivência dissidente no agora, que reivindica o direito de continuarmos existindo ao meio das políticas de extermínio enfrentadas pela população LGBT no Brasil e na América Latina. Utilizo-me da estética ficcional da distopia futurística e póspornográfica para fantasiar narrativas anti-coloniais e contra- hegemônicas. 0 projeto distópico que opera no hoje é racista, higienista, genocida e extremamente desigual, tendo no Estado um mobilizador de projetos desumanizadores com alvos declarados àquelas camadas que escapam do modelo hetero cis-patriarcal e branco ${ }^{8}$. Esse modelo ocidental semeado por aqueles que se impuseram como

\footnotetext{
${ }^{6} \mathrm{O}$ filme foi inteiramente financiado a partir de minha bolsa de mestrado do CNPq e com o valor do Prêmio Aquisitivo $2^{\circ}$ Salão/residência Eixo do Fora (Fundo de Apoio à Cultura/DF)

${ }^{7}$ CÔSTA, Pedra. The Kuir Sauvage. concinnitas | ano 17, volume 01, número 28, setembro de 2016. p. 356

${ }^{8}$ Exponho estes termos tendo consciência de meus privilégios de alguém que no Brasil possui a leitura de uma bixa branca miscigenada.
} 
possuidores das colônias no passado genocida e catequizador hoje colhe seus procedentes.

Costumo dizer que Ascensão e Queda das Bixas tinha uma urgência própria em existir. A obra nasceu de fragmentos de diários e de processos criativos dos temas que circundam minha pesquisa e imaginário. Em julho de 2016 fui selecionado para integrar a residência artística do Museu do Sexo Hilda Furacão aonde tive a oportunidade de conviver com outrxs potentes artistas dissidentes. Vivemos no maior complexo de prostituição do Brasil localizado no quadrilátero de Guaicurus, Belo Horizonte - MG. Durante as quase duas semanas que permaneci como residente morei no Hotel Stylus aonde tive artistas como Ventura Profana e Bruna Kury em minha convivência; elas mais tarde viriam a integrar o elenco do filme. Em Guaicurus, os dias pareciam ter outra dimensão. Lidávamos com uma pluralidade absurda de pessoas, camadas de violência e afetividade, que refletia em nossos corpos e mentes. Numa das conversas, falamos sobre o espiritual não institucionalizado presente em nossas vidas, a força da empatia dentro da comunidade LGBT e as estratégias de sobrevivência dos nossos corpos. Entre os papos e vivências avassaladoras surgiu o primeiro projeto que se chamava "Sebastianus", seria um trabalho de lambe-lambes que joga etimologicamente com o fim "anus" do nome do santo em latim. Naquele momento pretendia como parte desse projeto performar personificando São Sebastião. Uma vez vestido com uma indumentária que remetesse a suas flechas perfurantes e chagas, pularia entre as marquises de concreto-ruína das fachadas dos hotéis das putas. ${ }^{9}$

Profana também constantemente apropria-se da cultura sagrada cristã e a atualiza para difundir seus manifestos. Foi então que escolhemos Saint Sebastianus por ser um ícone subversivo associado a nós, bixas, que atua de dentro do próprio sagrado,

\footnotetext{
${ }_{9}^{9}$ Nessa época investigava e executava performances que me colocavam em risco de queda letal. Trabalhos como "Corpo Cadente", "Por cima do previsto" e "ande, não corra (série anti-atlética)" são exemplos disso. As duas últimas podem ser acessadas nos respectivos links: https://vimeo.com/177651942 e https://vimeo.com/202996853.
} 
sendo conhecido, dessa forma, desde o século XIX ${ }^{10}$. Diante da questão da representação dos corpos marginalizados nos ícones cristãos, esse santo vem sendo curiosamente absorvido; é o santo rogado em casos de doenças ${ }^{11}$, martírios e sofrimentos. As suas representações na cultura sacra são, constantemente, as de um homem andrógino e afeminado, geralmente indicando, em sua expressão facial, sinais de êxtase ou de desfalecimento. Existe uma conotação sexual em seu semblante que culmina no momento da quase morte, no qual, já amarrado, recebe flechas em diversos pontos do corpo. É um homem que possui o rosto mergulhado em prazer/agonia, sendo perfurado; é bixa.

Durante a experiência da residência lesionei meu tornozelo, e não pude fazer a ação da performance nas marquises, conforme havia planejado, e tampouco os lambes foram aplicados. As demandas da vida cotidiana eram de outra ordem e eu, como a maioria dxs outrxs artistas residentes, enveredamos para urgências que extrapolavam a criação de obras artísticas. Havia um hotel cujo quartos eram ocupados somente por transexuais e travestis, o Ruby, e ali também me chamou atenção a presença de alguns ícones sagrados. Logo, ao subir pela escadaria do local, me deparei com um painel neon vermelho de São Jorge, ou Ogum na cultura umbandista, com sua lança protetora. Comecei, a partir daí, a perceber com mais cautela a subversão de várias instâncias religiosas ao serem levadas para contextos marginais. Ao decorrer do filme Ascensão e Queda das Bixas resgato essas simbologias de subversão do sagrado. 0 sagrado que nos é imposto nega-se a nos comportar, então nos apropriamos dessa imposição que nos atravessa, para

\footnotetext{
10 ROSA, Fernando André. As flechas de São Sebastião, da renascença à sexualidade. Lisboa: ISCTE, 2009. Pág.4. Neste ensaio Rosa fala da origem do "apadrinhamento" da figura de São Sebastião pela comunidade $L G B T$, principalmente gay, partindo de sua androgenia, da metáfora entre as flechas e a penetração masculina. Além disso, Rosa traz um recorte histórico do dramaturgo britânico Oscar Wilde (1854-1900), que após ter sido condenado à prisão por ter tido relações sexuais consideradas contrárias à natureza na época, se converte ao catolicismo e adota o nome Sebastian, em referência ao santo.

${ }^{11}$ Ibid., p.4. Segundo Rosa, por ser um santo suplicado na cura de doenças e martírios, durante a epidemia da AIDS nos anos 80 a apropriação icônica de São Sebastião pela comunidade gay se estreitou ainda mais.
} 
criarmos nossas próprias narrativas.

\section{Os Simbolismos por Detrás de $A Q$ das Bixas}

$A Q$ das Bixas é formado por um bombardeamento vivaz de informações e simbolismos. Meu processo de criação se dá pelo processamento de dados visuais que percebo em meu cotidiano e que então ficcionalizo em obras de arte. Quando decidi convocar uma legião de artistas bixas, trans e não-binárias (muitas delas amigas minhas) para compor o elenco do filme levei em consideração, na maior parte dos casos, suas próprias poéticas e pesquisas artísticas, propondo elementos que conversassem também com suas trajetórias pessoais de criação. Dessa forma acredito que os simbolismos trazidos por suas personagens se adensam e tornam suas representações mais próximas dos interesses das próprias intérpretes. 0 filme video-artístico foi escrito com um pensamento de álbum-visual, ou seja, a narrativa visual é totalmente interligada à trilha sonora original ${ }^{12}$ composta para a obra e muitos dos planos e cortes de fotografia foram pensados a partir da influência de video-clipes ${ }^{13}$. Nas próximas páginas destacarei algumas cenas e personagens do filme entrelaçando-as a fragmentos de alguns dos conceitos que criei em $O$ desejo por trás da queda: Ficções e ritos do corpo bixa. Durante a escrita do texto dissertativo a pós-produção do filme estava sendo executada em paralelo para que a obra fosse estreada junto à defesa pública do mestrado, não existindo assim tempo hábil de esmiuçar teoricamente os pormenores do universo simbólico das entidades que protagonizam o filme. Tomarei este artigo como uma oportunidade de fazer esse percorrido em algumas das personagens, pretendendo estreitar os processos intelectuais aos práticos dentro de minha pesquisa e

\footnotetext{
12 A trilha sonora original do filme foi composta majoritariamente pela artista sonora chilena Antonia Valladares-Fischer com o auxílio dos produtores musicais Maxi Cat, Juan Peçanha e Jeza da Pedra.

${ }^{13}$ As escolhas de captura de algumas das cenas por parte do diretor de câmera Felipe Ferreira de Almeida e os efeitos especiais executados pelo montador Guerreiro do Divino Amor são também parte intensificadora dessa estética.
} 
corroborar para uma melhor assimilação de tais signos por quem assistiu ou potencialmente venha a assistir ao filme ${ }^{14}$.

A obra é um média-metragem dividido em três capítulos que chamo de Passos. Cada capítulo tem um prólogo que é uma espécie de cena introdutória para o conteúdo do Passo que vem em seguida. Tive a ideia de usar a termologia Passo pela quantidade de expressões da performance e da dança que integram algumas das cenas, nas quais são nítidas as influências no aspecto coreográfico provindas da estética de video-clipes. $A Q$ das Bixas não deixa de ser uma antologia de performances ou exercícios performáticos que se propagam à medida que vão entrelaçando-se aos fragmentos sentimentais vindos originalmente de meus diários ou composições musicais. Tanto a trilha sonora como os efeitos sonoros de transição e onomatopéia ${ }^{15}$ levam a uma rítmica intencional orientada por frequências de ascensão e queda a todo instante, que evocam ao título do filme. Um dos símbolos que reforçam esse ritmo de ascensão e queda é o arco-íris. Ao longo do filme um vídeo mostrando a formação de um arco-íris em diferentes estágios é exibido antes de cada prólogo. Na primeira vez surge ascendendo no horizonte de uma paisagem ensolarada, na segunda já aparece definido entre as nuvens do céu e na terceira some em queda pelas nuvens. Também escolho retratar o arco-íris antes de cada Passo por ser um símbolo que me acompanha há alguns anos dentro da pesquisa criativa, principalmente na série CROMAQUEER ${ }^{16}$ na qual arco-iriso em cores objetos de risco e queda como facas, cintos de carga de avião, pára-quedas, entre outros. Apesar de tradicionalmente trazer uma ideia de esperança na representatividade LGBT+ escolho o arco-íris também como símbolo de nossa luta persistente pela sobrevivência.

\footnotetext{
${ }^{14}$ A obra ainda encontra-se em circulação por festivais e mostras, porém num futuro próximo pretendo publicá-la em um veículo gratuito de streaming. 150 período total que levou para ter a obra Ascensão e Queda das Bixas pronta foi um ano, sendo oito meses de produção (07/2017 a 02/2018) e quatro meses de pós-produção (03/2018 a 07/2018). Durante cerca de seis meses eu e Antonia Valladares-Fischer trocamos intensamente informações e longos e-mails a respeito das faixas que compuseram o corte final do filme. Fischer em Santiago do Chile e eu no Rio de Janeiro.

${ }^{16} \mathrm{https}$ ///cargocollective.com/rodrigodalcantara/Cromaqueer
} 
Algumas questões simbólicas se repetem ao decorrer do filme, como é o caso da etimologia escolhida para os nomes das personagens. Cada entidade apresentada foi nomeada a partir da relação da personagem com a cosmogonia simbólica que se apresenta em sua cena. A subversão de nomes de raiz de mitologia ocidental grega ou cristã é uma das características mais recorrentes. Algumas das vezes o batizado se deu por neologismos ou jogos entre palavras pré-existentes no português, nunca sendo arbitrários. 0 processo de escolha de elenco também influenciou em algum dos casos, fazendo com que eu alterasse o nome, ou até mesmo o figurino e a estética da personagem a partir de quem assumisse o papel definitivo na cena. A seguir aprofundarei certos aspectos simbólicos relacionados à subversão do sagrado ocidental que estão presentes em $A Q$ das Bixas e para tanto darei ênfase nas personagens da abertura, do primeiro prólogo, do Passo I e de outras entidades que aparecem no Passo II do filme video-artístico. É de meu interesse dar continuidade em artigos futuros a esse tipo de análise das demais personagens de $A Q$ das Bixas em diálogo a outros conceitos que trabalho na teoria, traçando suas origens e relevâncias para a obra como um todo. As personagens analisadas a seguir revisitarão alguns dos conceitos trabalhados no meu texto de dissertação do mestrado que são relacionados à subversão e à atualização do sagrado cristão, principalmente o "estado entico performático" e a "queda disruptiva".

\section{A Guardiã da Chama e o estado entico performático}

O filme se inicia com uma cena de dança que precede o primeiro prólogo, acompanhada do seguinte texto:

\footnotetext{
"Nessa terra, de primeiro, reinavam em harmonia grupos múltiplos de jubilo e regozijação e então aqueles que só sabiam usurpá-la dominaram. 0 comando ali era da heterossexualidade compulsória e endêmica. Por alguns mil anos erodiram e secaram a tudo e todas. Oprimiram e mutilaram múltiplas. Tentaram decair até a última gota de paixão dos corpos, concretaram as sinuosidades, erradicaram a natureza e então vieram as bixas. Nas caladas e surdinas elas, preteridas, deferidas e desamadas, ressurgiram como entidades. Em seus olhos o sangue
} 
fervente pulsa pelos corpos que bailam e nunca deixam o sol pleno de suas faces. Uniram-se todas as rejeitadas à margem. Especializarem-se. Aprenderam a lidar com a iminência de suas quedas. As queriam nos fundos dos penhascos, insólitas. As tiveram férteis e prósperas como sempre hão de ser (D'ALCÂNTARA, 2018, 38'17)".

Essa cena foi inspirada de primeiro por fogueiras feitas pelas ruas da cidade do Rio de Janeiro e o simbolismo primordial ao mesmo tempo que pós-apocalíptico que elas elucidam. As observava entre os cruzamentos de viadutos, isoladas e brilhantes, no trajeto de ônibus até a Ilha do Fundão, aonde ia para assistir as aulas do mestrado. A cena foi gravada em um terreno baldio situado à frente do Galpão de Pós-Graduação da Escola de Belas Artes da UFRJ. A princípio a cena seria somente uma grande fogueira interpolada pelo texto acima, simbolizando um fogo de resistência, um manifesto visual em reforço ao manifesto escrito. Posteriormente x performer e cantorx Mc Caten foi convidadx para elaborar uma dança de improviso relacionando-se com a fogueira. Caten é professorx de dança, possuindo rica bagagem de expressão corporal comumente atuando em diversos gêneros de dança afro. Para que os movimentos corporais de Caten estivessem espiritualmente relacionados ao poder simbólico do fogo fui dirigindo-a com frases que estimulassem seu imaginário nesse sentido. A chama passou a fazer parte de sua dança à medida que Caten flertou com as labaredas e se apossou do simbolismo da chama. A invoco como Guardiã da Chama, a entidade que preserva o fogo primordial das bixas nesse futuro distópico. Gravamos a cena em algumas horas, no breu pós- apocalíptico que se instaura no Fundão quando vai se aproximando a noite. A palha seca das redondezas jogadas por Ventura, por Felipe Ferreira, por mim e pela própria Caten, sustentava o fogo aceso junto à garrafa de álcool e querosene que ateamos inteiras. 0 figurino foi feito com referência em roupas de editorial de moda esportiva, com meias brancas rasgadas e transformadas em abraçadeiras para os braços e pescoço. 0 saião preto foi pego emprestado da mãe de Caten e os seus olhos foram maquiados pela amiga Profana, na cor majenta como o céu distópico daquela noite ${ }^{18}$. A Guardiã da Chama será

17 Trecho de texto introdutório do filme Ascensão e Queda das Bixas (AQ das Bixas). 38'. Rodrigo D'Alcântara, 2018.

${ }^{18} \mathrm{~A}$ cena é a primeira a aparecer no filme e foi a última a ser gravada em fevereiro de 2018. 
aqui analisada em diálogo ao conceito que criei para tratar do estudo da performance, denominado de "estado entico performático ${ }^{19 " . ~}$

A entidade que emerge do corpo de um performer se faz através da afetação iconológica, vinda de seu repertório vivencial, da intromissão do ambiente (e ocasionalmente do público) e das circunstâncias que envolvem dado movimento corporal escolhido. Ao ser performer e ao dirigir outrxs performers comecei a notar que existe uma noção entica, de entidade, para acessar ao próprio corpo, que entendo como uma assimilação de estímulos extracorpóreos e que logo podem se desencadear em improviso, dança e/ou deslocamentos da extensão corporal do estado regular de quem se propõe a um programa performativo ${ }^{20}$. Por estado regular entende-se o rotineiro, o vocabulário cotidiano rígido de limites e fronteiras corporais que cada pessoa contém, ou lhe é imposta. Há que se levar em conta que uma presença corporal humana é singular e atuante por si só, apenas por existir e ocupar um espaço e um bioma social. Na performance, acredito que há, muitas vezes, uma reverberação consciente da presença corporal num dado ambiente e, então, uma extrapolação das fronteiras estruturadas previamente a tal presença. Cria-se uma nova presença, uma aparição de um corpo até então não compreendido, para fora de suas funcionalidades e merismas habituais; um corpo em trânsito, um corpo mediúnico, que é canal da performance.

\footnotetext{
${ }^{19}$ Para aprofundamentos sobre o estado entico performático consultar: D'ALCÂNTARA, Rodrigo. "O desejo por trás da queda: Ficções e ritos do corpo bixa". UFRJ: Rio de Janeiro. 2018. Pág.75

${ }^{20}$ FABIÃO, Eleonora. Programa performativo: o corpo-em-experiência. Unicamp. Revista do Lume. n.4, dez. 2013.
} 


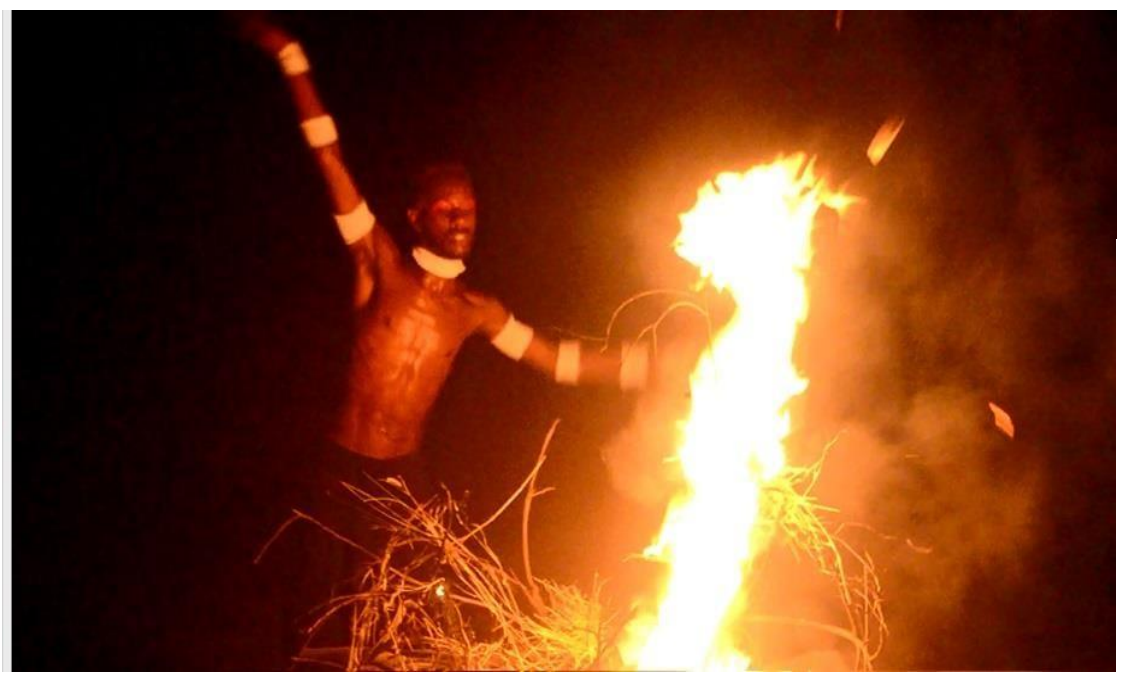

Imagem 2:

Mc Caten como

Guardiã da

Chama.

Ascensão e Queda

das Bixas

Direção: Rodrigo

D’Alcântara. 38'.

2018

Nesse sentido, a performance aproxima-se das práticas de médiuns espíritas, umbadistas e candoblecistas ao, também, se expandir através de dinâmicas de incorporação e desincorporação nas quais o corpo centraliza os processos ${ }^{21}$. As performances em Ascensão e Queda das Bixas dizem muito do estado entico que aqui busco entender, que pulsa e se expressa no corpo de quem permite ser permeado por ele. Acessar a esse estado diz respeito a um conjunto de fatores que permitem essa fruição como: a consciência da extrapolação de presença corporal, o uso de entorpecentes (em alguns dos casos), a situação do ambiente (música, barulhos, silêncio, retaliação do público, interação do público, etc.). A performance no estado entico tem no corpo bixa um meio de expressão. Ser parte do corpo bixa já é rasgar com a presença corporal regular; é ser um ruído performático constante dentro do hétero cis-tema. Capitais de herança colonial como o Rio de Janeiro, aonde os olhos cruzam fogueiras entre ruínas e moradores de rua, são sedes do poder ficcional, e geram fantasias que legitimam as atrocidades e usurpações de direitos às vivências dissidentes. Jota Mombaça vai dizer que essas ficções são, materialmente, engajadas na produção do mundo, no sistema de perpetuação da

${ }^{21}$ RODRIGUES, Graziela; TURTELLI, Larissa. Umbanda e método Bailarino-Pesquisador-Intérprete (BPI): confluências. p.143. 
justiça moderno-colonial ${ }^{22}$ que vivemos. Como funciona um corpo que se deixa ampliar e fluir diante de um contexto civilizatório que o deslegitima? Como criar suas próprias ficções corporais ressignificando a opressão?

"A dissociação entre a ação e o agente pode ser como testemunhar uma pessoa em transe ou em estado de choque" (STUART, 2011, p.156, tradução livre)

O trecho citado acima foi retirado de uma sessão de proposições performáticas contidas no livro Are we here yet? (Ainda estamos aqui?), de Meg Stuart. A autora, performer e coreógrafa de dança contemporânea, traz, em seu livro, exemplos de uma série de expansões e extrapolações dos sentidos e significantes corpóreos entre a ação e o agente dados através da performance. Nos seus mais diversos módulos, Stuart (2011) propõe desconstruções de noções preconcebidas, desantropofizações, deslocamentos das noções de tempo/espaço, perda de identidade, concentração em pontos corpóreos específicos, auto-desindentificação para reintegração de si, entre outras formas de (des)entendimento do corpo através da dança/performance. Entendo alguns dos exercícios de Stuart como bastante pertinentes à discussão do estado entico na performance e a viabilização de ficções pessoais do corpo bixa performático. São eles: A última pessoa na Terra, Eu não estou lá, $\mathrm{O}$ corpo não é seu, $\mathrm{O}$ corpo como hospedeiro e Fantasmando a si mesmo $^{23}$. Explanarei, sucintamente, aspectos sobre cada um desses cinco modos, entendendo-os como proposições que se alinham ao estado entico.

Em “A última pessoa na Terra", a proposta de situação corporal é partir do pressuposto que seu corpo passou por um acidente ou situação traumática e você é o último sobrevivente da catástrofe que acometeu à Terra. 0 corpo num estado de paralisia se mantém fixo ao chão até que, gradamente, os movimentos se recobram, iniciando-se pelos olhos, com a concentração perceptiva restrita ao aparelho óptico. Nesse processo lento de retomada de consciência do corpo e

\footnotetext{
22 MOMBAÇA, Jota. Rumo a uma redistribuição desobediente de gênero e anticolonial da violência! Fundação Bienal de São Paulo, 2016. p.4.

23 Todas os títulos aqui trazidos são traduções livres feitas por mim. Originais, respectivamente: The last person on Earth, I'm not there,The body is not yours, The body as a host, Ghosting yourself.
} 
reconhecimento do que/quem é você e o que está a sua volta, cada vez mais a sensação, a expressão e o poder se presentificam em seu corpo ${ }^{24}$.

"Eu não estou lá" é uma profusão de ações dissonantes. 0 olhar deve ir em direção oposta aos movimentos dos braços. As ações do olhar são desassociadas do restante do corpo. Stuart sugere que você se recuse a saber, ou não saiba de fato, o que seu corpo está fazendo. 0 corpo está presente e você ausente ou vazio ${ }^{25}$. “0 corpo não é seu" tem algo de semelhante, sendo um jogo de tensão entre controle e entrega do corpo. As partes corporais possuem vida própria e você não é mais o agente do movimento. É uma proposição de permissão do corpo a se perder.

Numa lógica mais plasmática, "O corpo como hospedeiro" é sugerido compreendendo que existem energias externas e internas que devem fluir no corpo em evidência pela a ação performática. Stuart propõe que essas energias ora invadam, ora transbordem do corpo, eventualmente, influenciando seus movimentos. Já em "Fantasmando a si mesmo" a autora provoca a performance para situações extremas deslocando a intensidade emocional para diversos lugares do corpo até chegar a um estado de fantasmagoria de si, um corpo que se torna mera superfície, vazio, desconectado ${ }^{26}$.

Em todos esses modos existe uma disposição do corpo a práticas que extrapolam os limites impostos pelo regime normatizado. Meg Stuart coreografa o corpo de maneiras tão múltiplas e fragmentárias que o situa como invólucro a ser experienciado e desafiado. Quando se performa conscientemente pelo estado entico, o corpo e o local da performance dialogam entre quem irá afetar ou ser afetada. Acredito que uma das principais questões levantadas por Stuart nesses exercícios que elenco acima, é a da ambivalência da consciência corpórea ora estando em sua máxima ativação afinada ao corpo performático, ora estando em total discordância, explorando justamente a possibilidade e potência do desvinculo entre mente e ação. Essa ambivalência opera o estado entico ao

\footnotetext{
24 STUART, Meg. Are we here yet? Les presses du reel. Paris: 2011, p.154.

25 Idem. p.156.

26 Idem. P. 160.
} 
permitir que o corpo flua a consciência para áreas que normalmente não seriam exploradas e dão vazão à ocupação desse corpo no espaço. Em toda proposição performática operam códigos ficcionais que são canalizados de acordo com a vivência corporal de cada pessoa. Portanto, se o corpo deixa de ser o foco da consciência e a ação se torna o centro da movimentação, como instrui Stuart em seus exercícios, a performance é entica. No estado entico, a consciência em sua forma pulsante e presente se dá, então, num intermeio, na conversa entre mente e invólucro carnal. Justamente pela performance reforçar a presença do corpo, destaca-se o que difere; elucida-se o que parece ser transe e sublima-se o que é chocante quando as pessoas que recebem a ação como público em sua maioria ainda estão programadas para seguirem protocolos rígidos limitados à associação entre ação e agente 27 .

A última pessoa na Terra, Eu não estou lá, 0 corpo não é seu, 0 corpo como hospedeiro e Fantasmando a si mesmo. Revendo aos nomes das proposições de Meg Stuart, percebo que o corpo bixa em seu desenvolvimento social passa por todas essas etapas performáticas sem se dar conta. Por não nos adequarmos à hegemonia, nossos corpos crescem a princípio em desconexão com o seu redor, criando novas formas de pertencimento e posturas próprias, desde as primeiras etapas de construção da consciência corporal. Não existe representatividade sistêmica para o corpo bixa, não existe instrução; é um corpo desordenado, escancarado e invadido que vive como resposta. Talvez o estado entico performático surja, em sua maior potência, quando acessado por um corpo bixa, pois estabelece um contexto propício a expurgar opressões, mostrar nossa maravilhosidade em desobediência. 0 "entico" que canalizamos ao performar vem dessa energia da margem, dando respostas ao núcleo cis-hétero normativo. Damos vazão as nossas próprias ficções e ritos subversivos que operam, somente, em nossos corpos e atualizamos o hétero cis-tema . 0 corpo bixa é uma gênesis performática que hibridiza masculino e feminino, cria novos gêneros e extrapola

\footnotetext{
${ }^{27}$ Idem. p.156.
} 
o que é esperado de um corpo.

\section{Arauta, Anjo Caído, Candelária e a queda disruptiva}

"Passo 1:Valência; caso o peso seja sagrado, o levante será profano". (D'ALCÂNTARA, 2018, 38'28)

O primeiro Passo do filme Ascensão e Queda das Bixas chama-se Valência e é caracterizado por entidades que subvertem o sagrado católico. Tal título refere-se tanto ao ato de ser valente como uma alusão irônica à cidade tradicionalmente católica de Valência, na Espanha, que segue até a atualidade como referência de cristianismo ortodoxo eurocentrado. As entidades que compõem este capítulo são: Arauta interpretada por Ventura Profana, que surge protagonizando o prólogo deste capítulo; Anjo Caído interpretada por mim (Rodrigo D’Alcântara); Candelária interpretada por Cassie Capeta. Por considerar que as personagens que surgem neste Passo são interligadas, analisarei as três entidades, em consonância ao conceito de "queda disruptiva" 29 , trabalhado originalmente em minha dissertação.

O prólogo deste Passo se inicia com a personagem Arauta, de Ventura Profana sendo anunciada como "a primeira mensageira", é também a imagem vertical escolhida para abrir este artigo ${ }^{30}$. Os Arautos na idade média eram os mensageiros oficiais dos reinados, que proclamavam solenidades e eram responsáveis pelo anúncio tanto dos tratados de paz como as guerras ${ }^{31}$. Quando estava no processo de escrita do roteiro do filme fui atravessado por esse nome ao procurar informações online sobre personas da antiguidade ocidental. 0 titulo de Arauto originalmente vinculado a figuras masculinas é dado então para Ventura em sua

\footnotetext{
${ }^{28}$ Trecho de texto introdutório do filme Ascensão e Queda das Bixas (AQ das Bixas). 38'. Rodrigo D'Alcântara, 2018.

${ }^{29}$ Para aprofundamentos sobre o conceito de queda disruptiva consultar: D'ALCÂNTARA, Rodrigo.

"O desejo por trás da queda: Ficções e ritos do corpo bixa". UFRJ: Rio de Janeiro. 2018. Pág.75

${ }^{30}$ Pág.2

${ }^{31} \mathrm{https} / / /$ pt.wikipedia.org/wiki/Arauto
} 
primeira versão feminina. Ventura Profana é performer e cantora, tendo em sua pesquisa artística um meio de propagação do sagrado evangélico a seus próprios termos. A artista vê seu trabalho como um manifesto "a favor das vidas dissidentes, estranhas e monstruosas, reivindicando o direito de viver plenamente"32. Comumente Profana personifica a figura de pastora em suas performances, trazendo a palavra travesti para ressignificar o sagrado. A criação dissidente passa pela vivência que o hétero cis-tema designa a morte, a resposta é o transbordamento de vida.

Arauta surge olhando fixamente o horizonte da câmera em ruínas de um coreto de aspecto greco-romano pichado por grafismos e grafites. Seus olhos procuram por vida enquanto ofegante ela sustenta apenas uma corda branca enroscada em seu pescoço como adorno. Em seguida aparece correndo, em fuga constante, por campos silenciosos. Logo surge em cima de um aglomerado de pedras na frente de uma queda d'água, equilibrando-se em diversas posições enquanto ao fundo escutam-se as palavras "força, proteção e equilíbrio". 0 prólogo encerra-se com Arauta debruçada no monumento em homenagem ao centenário do imperador colonizador Pedro II $^{33}$, empossando-se dos ornamentos e vasos que compõem a arquitetura. O Passo I inicia-se com o anúncio da personagem Anjo Caído, “a querubina que habita as ruínas do antigo sagrado", junto ao portal de ruínas de uma igreja da época colonial ${ }^{34}$. A personagem Anjo Caído é um ícone de subversão do sistema católico, do antigo sagrado. A querubina possuí seu corpo coberto de cal branco, deixando apenas a face e os cabelos loiros oxigenados expostos. Nas costas da personagem existem duas marcas vermelhas feitas na altura das escapulas que sinalizam suas asas cortadas. Sua estética representa essa constante atualização proposta pelas vivências dissidentes, ao criarmos nossas próprias percepções e propagações do sagrado que nos é imposto. A Anjo dança pela

\footnotetext{
${ }^{32} \mathrm{https}$ //friction-magazine.fr/ventura-profana-enfant-des-entrailles-mysterieuses-de-la-merebahia- bresil/ último acesso em janeiro de 2019. Tradução livre.

${ }^{33}$ A cena foi inteiramente gravada na Quinta da Boa Vista, RJ.

${ }^{34} \mathrm{~A}$ cena foi inteiramente gravada nas Ruínas de São José da Boa Morte, no município de Cachoeiras de Macacu, interior do Rio de Janeiro.
} 
arquitetura e joga com o sol até desaparecer nas sombras do divino em ruínas. $\mathrm{Na}$ cena de transição aparece então apenas a sombra da personagem abrindo seus braços em forma alada sobre as pedras do antigo sagrado através do sol que incide nas ruínas.

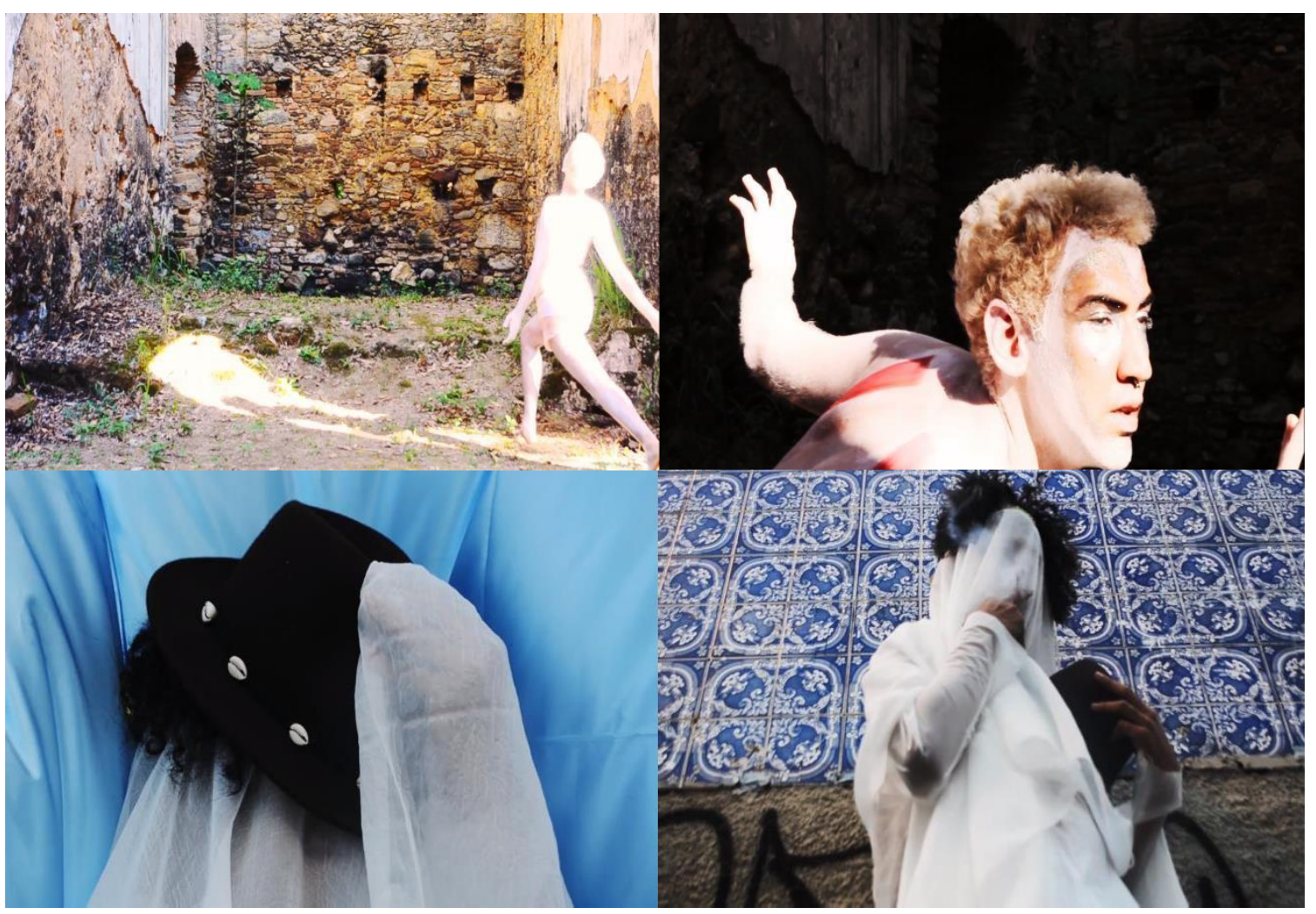

Imagem 3: Rodrigo D’Alcântara como Anjo Caído, "a querubina que habita as ruínas do antigo sagrado"/Cassie Capeta como Candelaria, "a que compreende demandas". Ascensão e Queda das Bixas. Direção Rodrigo D’Alcântara. 38'. 2018

Candelária ${ }^{35}$ surge então, em seguida, como "a que compreende demandas". Com um chapéu marrom adornado com guias de búzios ${ }^{36}$ e no fundo um tecido azul de cetim. A composição inicial é interpolada por uma outra cena em que Candelária fuma um cigarro ainda que com o rosto coberto por um véu de noiva. Enquanto

\footnotetext{
${ }^{35}$ Em referência à Nossa Senhora da Candelária. Na América Latina também é comum que hajam regiões centrais em grandes capitais com o mesmo nome, herança da arquitetura de passadocolonial. 360 chapéu fazia parte do acervo pessoal de criação do Diretor de Figurino do filme Juan Romar e foi adicionado à cena. 0 vestido da personagem também foi costurado pela própria atriz que protagoniza a cena, Cassie Capeta. As vestes provindas das urgências vieram a contribuir para a frase de anunciação da personagem como a que compreende demandas.
} 
fuma, azulejos da Paróquia Nossa Senhora da Lapa (RJ), ornam o fundo da cena com mais uma atualização de igreja de arquitetura colonial. A câmera volta para a composição anterior aonde agora o cetim azul cai revelando a paisagem atrás da personagem, o bairro da Lapa e o topo ensolarado da Paróquia Nossa Senhora da Lapa, tendo sido a única cena em que aparecem transeuntes, existindo portanto um público que atuou diretamente na construção da performance da atriz. Nos bastidores das gravações diversos moradores de rua e outros homens que caminhavam pela Lapa assoviavam e assediavam à atriz. Seu figurino todo branco que incluía o véu gerou uma associação direta do público à figura de uma noiva. Os homens automaticamente demonstravam interesse em casar com Candelaria. Sua presença plácida de noiva ambígua coloca em cheque os valores tradicionais conservadores de nossa sociedade hipócrita cristã. Candelária finaliza sua aparição jogando seu véu na frente de um paredão aonde se lê pichado "nem deus, nem estado, nem marido, nem patrão, nunca." As três personagens do Passo I formam uma tríade a partir da anunciação do Passo de que "caso o peso seja sagrado, o levante será profano". O peso do antigo sagrado quer nossas quedas, então me aproprio desse lugar de instabilidade como potência simbólica. Trabalho a partir daí o conceito de "queda disruptiva". A queda disruptiva, conforme o termo queer, é um conceito que proponho a ser mutável, definindo-se como a presença do corpo à margem em desobediência diante do cenário de opressão que se apresente. Cair disruptivamente viola o esperado para nossos corpos dissidentes e recria a potência da queda. Infiltramos o sistema hegemônico agindo desobedientemente de dentro dele, forçando-o a se modificar, transmutando-o e não o rompendo de imediato.

A masculinidade exacerbada e opressora faz parte da fundação da instituição católica e reverbera duramente nas vivências de pessoas LGBTs. No filme Sebastiane (1976), os diretores Derek Jarman e Paul Humfress constroem uma narrativa inteiramente pensada a partir da transgressão do universo masculino presente no sagrado, explicitando, justamente, a hipocrisia que carrega o discurso cristão. O filme é repleto de erotismo e é uma ode aos corpos masculinos 
sexualizados, gozadores e profanos. Uma intenção muito nítida é reforçar a imagem de São Sebastião como um ícone homossexual. 0 enredo do filme mostra, a partir de um ponto de vista homoerótico, a protagonista Sebastiane, que a todo instante reluta em se entregar ao Comandante Severus, que deseja fixamente a protagonista. A relutância sexual de Sebastiane culmina na famosa cena de sua morte: amarrado a um mastro recebe, por ordens expressas do Comandante, vários lances de flechadas enquanto seu semblante plácido está voltado para os céus. 0 desejo não concretizado em sexo gera um recalque, que faz com que Severus consuma, finalmente, a perfuração do corpo de Sebastiane. São Sebastião possui uma postura de abnegação diante da morte, em detrimento do desejo carnal, fruto de seu forte vínculo com a fé cristã. 0 que orbita seu olhar siderado 37 sempre voltado para o alto me parece ser, justamente, seu desejo pela ascese ${ }^{38}$, porém alinhado à linguagem corporal erótica na qual o sol aparece dubiamente como perigo ou salvação de seu corpo desviante.

Sebastião ainda sendo alvo das investidas de penetração, nutre o desejo principal ao astro-rei, sua fonte maior de admiração e anseio, que o torna um fiel. Mesmo com toda sua bagagem andrógina e legado homoerótico, São Sebastião ainda opera dentro do modelo messiânico de fidelidade à queda cristã ${ }^{39}$. De todos os modos, suas representações profanas e blasfêmicas auxiliam, consideravelmente, a burlar com as normas sagradas partindo delas mesmas. Ainda que seja através de um sol canônico, Sebastiane, como bixa andrógina, põe a cara no sol deixando sobressair

\footnotetext{
${ }^{37}$ MONDZAIN, José-Marie. Sideração. Rio de Janeiro : Zazie Edições : 2016. p.10. Mondzain coloca o termo sideração como o inesperado encontrado pela contemplação de algo externo.

38 Ascese é um conceito cristão de que os mortais receberão sua libertação somente ao caírem matéricamente, ou seja, ao morrerem e se elevarem espiritualmente; para mais teorias sobre o assunto consultar os tópicos "O ânus e o sol" e "O ímpeto de Ícaro". D’ALCÂNTARA, Rodrigo. 0 desejo por trás da queda: Ficções e ritos do corpo bixa. UFRJ, Rio de Janeiro. 2018. Pág. 19 a 36.

39 "O repertório que compõe os cenários de Igrejas católicas engloba santidades em posição de êxtase, de desfalecimento e, muitas vezes, de quase delírio, de corpos em queda. Acredito que o regimento da queda, nesse tipo de imagem santa, é parte integrante de algo maior, de um sistema de fidelidade à queda cristã. Os fiéis são espectadores do celestial e funcionam como um elemento deslumbrado ao sistema de imagens que nutrem, depositando na matéria a culpa e a abnegação."Ibid. Pág.17 a 21.
} 
sua feminilidade ${ }^{40}$. 0 filme inteiro é falado em latim e possui muitas cenas gravadas ao sol estridente, o que gera um teor epopeico pulsante reforçado na linguagem cinematográfica, tendo sido referência para o Passo I de Ascensão e Queda das Bixas.

Partindo de Sebastiane e sua relação com o sagrado, remeto-me ao mito de Ícaro para acionar uma rede de pensamentos que nutrem um imaginário da queda desobediente pertinente às personagens acima. Segundo o mito, em suma, Ícaro e seu pai, Dédalo, viviam encarcerados numa torre dentro do labirinto do Minotauro, fruto da condenação recebida a Dédalo por ter empurrado o melhor de seus aprendizes num penhasco, por inveja. Dédalo, maquinando ideias para libertar a ambos da espécie de limbo que viviam, finalmente cria engenhosamente dois pares de asas, a partir de penas de pássaros que, ocasionalmente, caíam ao seu alcance na torre. Colando essas penas com cera, concebeu asas aos moldes seus e de Ícaro. Ao chegar o dia da fuga, Ícaro contraria os conselhos de seu pai e aproxima-se muito do sol, despencando para a morte em queda-livre.

No livro Memórias de Cego, de Jacques Derrida, ao decorrer de todo o texto, de maneira intermitente, há alusão à queda. A temática da queda vinculada à cegueira no livro é pertinente para o diálogo com o simbolismo de São Sebastião, apresentado anteriormente e que também influencia o título do segundo Passo, “Olhos Caídos”. A queda, para Derrida (2010), é uma face importante perante a desconstrução dos aspectos perceptivos do aparelho óptico. 0 autor protagoniza a figura do cego como agente dessa mudança de assimilação visual. 0 cego age na instância do precipício, explora a partir do apalpar, da extensão do que deve reconhecer sem ainda a conhecer, é uma espécie de instrumentador do tátil e da iminência da queda, do acidente, do risco, da morte- "e o que na verdade (...) apreende é o precipício, a queda - e ter já franqueado alguma linha fatal, com a

\footnotetext{
40 "Põe a cara no sol, mona! Põe a cara no sol, querida! Aceita gay, é pra poucas a cara no sol, mona! Bicha bonita não se esconde, mostra o rosto, a feminilidade." Bordão viralizado na internet, criado pela blogueira travesti Natasha Martory.
} 
mão desprotegida ou armada"41. A falta da visão geraria, então, corpos desajustados, estabanados e tropeços, que precisam fluir e desconstruir a lógica hegemônica do olhar.

Derrida situa o cego como um ser exposto, nu, suscetível além da queda, ao desdém e ao castigo pelas possíveis intempéries que lhe acometam ao redor. A cegueira não seria uma falta da visão, senão uma forma outra de olhar. Da mesma maneira que a ausência de visão pode ser tomada como punitiva, outras vezes é tida, pelo autor, como algo que beneficia ao indivíduo cego, ainda que de um ponto de vista espiritual, uma renúncia próxima da cristã. Um exemplo dado pelo autor, voltado para essa ambiguidade do gesto de cegar, é o contexto por detrás da obra "A Morte de Orion", de autoria da Escola de Fontainebleue. Orion deseja ao sol e é punido pela violência de seu desejo ${ }^{42}$. Em uma miscelânea mitológica, Derrida traça a morte de Orion como uma sucessão de revanches e testemunhas divinas da cegueira que antecedem sua morte solar. Carregado por entidades - Enopion e Cedalion -, Orion é finalmente morto pelo deslumbre do astro rei. 0 autor destaca o olhar do outro, o olhar de quem vê vir ${ }^{43}$, no caso o olhar das entidades e do próprio sol que cegou a Orion que, através de sua cegueira e conseguinte queda, desperta a visão de terceiros. Dessa maneira, Derrida reforça a desconstrução da noção de visão para além do olhar vidente e para além da esfera matérica. Ainda em Mémorias de Cego, há também a figura de Paulo/Saulo que é citada pelo autor como um dos expoentes da cegueira sublimada. Saulo cai de seu cavalo e, voltado para os céus, recebe a sua conversão ao cristianismo. Ele é derrubado pelo deslumbramento de uma luz cegante divina que o enche de fé e entendimento.

Analisando em conjunto as três personagens desobedientes- São Sebastião, Ícaro e Orion - as orbitam a contemplação, a morte e o sol; A contemplação inquieta é o

\footnotetext{
${ }^{41}$ DERRIDA, Jacques. Memórias de Cego: 0 auto-retrato e outras ruínas. Tradução: Fernanda Bernardo. Lisboa: Fundação Calouste Gulbenkian, 2010. p.12.

42 Ibid., p.107.

${ }^{43}$ Ibid., p.108.
} 
que coordena o foco dos esquemas ópticos das personagens; a morte é sempre mediada por alguma intervenção divina, seja ela de origem católica ou não e, geralmente, aparece como um ato punitivo pelas ações ou trejeitos subversivos de quem a protagoniza; o sol é o objeto do desejo, testemunha e/ou agente da cegueira dxs protagonistas. Diferentemente de São Sebastião ${ }^{44}$ e de Orion, Ícaro cai triunfante; assume todos os riscos de sua ação e desbrava o sol, não apenas o contempla. Suas asas miméticas são derretidas pelos raios enquanto plana em demérito às leis celestes. Sua queda é apropriada pelo discurso cristão, posteriormente, como símbolo a não ser seguido. Ele é visto como a figura do herege, que deve servir de exemplo a aquelxs que infligem as regras ditas superiores.

O sol é o fogo que consome Orion, é o olho que fascina outros olhares e testemunha a morte de Ícaro e é, ainda, metáfora para o plano divino e encerramento da matéria humana para Sebastiane. 0 corpo bixa em queda disruptiva deve infiltrar o sol, o núcleo, de alguma forma, e engoli-lo como Ícaro ao ascender ao sol para a própria queda o faz contrariando a ascese, diferente de Paulo/Saulo. É assim que entendo, pelo mito de Ícaro ${ }^{45}$, o símbolo emblemático de mudança ao ideal do fiel cristão. 0 Ímpeto de Ícaro imbrica, então, a queda como meio de subversão, como escolha e intencionalidade de transformação de um regime icônico normatizador pré-estabelecido. Ele representa a emancipação da lógica cristã ao contrariar os comandos divinos e rechaçar a punição abnegada. Ícaro constrói asas próprias para escapar de uma condenação de cunho divino, infligindo às regras impostas pelos céus, está sempre em fuga, e, no fim, é um humano eternizado como um anjo caído. Seu ímpeto de desafiar o sol consuma a queda disruptiva ao sistema icônico cristão. Essa desobediência pagã pertence ao corpo bixa.

\footnotetext{
${ }^{44}$ São Sebastião aqui refere-se à personagem Sebastiane, no longa-metragem homônimo de Derek Jarman que narra a vida do santo a partir de uma perspectiva homoerótica.

${ }^{45}$ Outras obras minhas que abordam a relação do corpo bixa cadente em diálogo com o sol referenciando Ícaro são "Icarus Versus” (2018) e “O Êxtase” (2018).
} 
Na morte de Ícaro as duas testemunhas oculares são Dédalo, que é sua figura paterna, e o sol, que é sua figura celeste. Dentro da desconstrução constante, proposta por Derrida (2010), infere-se que o jogo entre visibilidade e cegueira depende sempre de um ponto de vista. 0 próprio Ícaro é testemunha de sua queda e morte. Assim como no caso de Orion que, ainda na condição de cego, instiga o olhar testemunhal àqueles que estavam ao seu redor. No fim, dentro do viés desconstrutivo proposto por Derrida, todxs aqueles que pretendem ter percepções mediadas são testemunhas e toda testemunha é cega ${ }^{46}$. Quem vive em dado meio social, em condições de pensar sua posição ocular, escolhe suas hierarquias, seleciona qual grupo tornará invisível ao seu testemunho, qual corpo será olhado do centro (núcleo) e qual à margem. Quando se está engendrado na margem do sistema hegemônico, o corpo entra em colapso direto com os códigos que o fazem diferir, assumindo a queda disruptiva. A sub-versão vem do lugar do des-privilégio de uma minoria reprimida que resiste e avança dentro da conduta straight ${ }^{47}$, não desviante, que pretende drenar as desviantes e condicioná-las às suas normas. As que permanecem não-catequizáveis são, então, postas na beira, aonde não há como prever riscos.

\section{Resquícios da subversão do sagrado no Passo II e considerações finais}

"Passo II: sobre os polos masculinos de violência floresça e impere feminina". (D'ALCÂNTARA, 2018, 38'48)

O segundo Passo chama-se Olhos Caídos e é caracterizado por conflitos e diálogos entre os pólos masculinos e femininos, empoderando o feminino. Neste tópico falarei do universo simbólico de apenas três personagens que ainda ecoam

\footnotetext{
${ }^{46}$ Idem. p.108.

47 PRECIADO, Paul Beatriz. Multidões Queer: notas para uma política dos "anormais". v.19, n.1. Florianópolis: Revista Estudos Feministas, 2011. “O corpo straight é o produto de uma divisão do trabalho da carne, segundo a qual cada órgão é definido por sua função”. p.3.

${ }^{48}$ Trecho de texto introdutório do filme Ascensão e Queda das Bixas (AQ das Bixas). 38'. Rodrigo D'Alcântara, 2018.
} 
conceitos trabalhados no caminho aqui percorrido, são elas: Andaluz, interpretada por Rafael "Uhura" Bqueer ${ }^{49}$; Nova-Hera interpretada por Giorgia Narciso e Dioneia interpretada por Lyz Parayzo.

No contexto ocidental quando uma ação de performance artística possui umx espectadorx, $\mathrm{x}$ mesmx tende a tachar x performer como esquizofrênica, louca, desequilibrada, histérica, vagabunda, entre outros termos depreciativos, principalmente quando a ação se dá no âmbito público. 0 espectador geral não é instruído a testemunhar o estado entico performático, muito pela raiz conservadora de nosso sistema, que condiciona o público a experienciar nudez, rompantes e extrapolações do corpo, quando na esfera privada; que dirá de tentativas de desconexão entre corpo e consciência. Na passagem do século XVIII para o XIX houve muitas mudanças na cultura da percepção ótica ocidental. A figura do espectador, antes atrelada à cultura de carnaval de rua e boemia, começou, aos poucos, a ser introduzida a um regime privado de consumo de imagens vinculado ao avanço de equipamentos óticos de entretenimento que, posteriormente, privatizaram massivamente a circulação das pessoas para dentro de instituições em detrimento do espaço público, concomitante à formação de plateias modernas ${ }^{50}$.

Ainda que o avanço do regime ótico tenha acentuado essa hostilidade a quem se mostra para além do estado convencional da presença do corpo em sociedade, isso é algo, antes, proveniente da cultura de valores cristãos católicos arraigados no ocidente. $\mathrm{O}$ corpo humano em si já é visto como algo profano dentro do sagrado. 0 corpo que contém qualidades do feminino é ainda mais execrado. A mulher dentro do contexto cristão sempre foi diminuída, perseguida e apagada historicamente

\footnotetext{
${ }^{49}$ Suas personagens foram creditadas como Rafael \& Uhura Bqueer no filme. Rafael Bqueer é artista bixa oriunda do Pará que possui como uma das vertentes de sua pesquisa artística questionamentos das normas de gênero, o que inclui sua personagem Drag Queen afro-futurista, UhuraBqueer.

50 CRARY, Jonathan. Géricault, o Panorama e os Espaços de Realidade no início do Século XIX. Tradução: Joana Negri. Revista ECO-Pós, Transformações do Visual e do Visível, V.17, N.2, Rio de Janeiro: 2014. p.4.
} 
pela misoginia predatória. Figuras femininas foram lançadas às fogueiras como bruxas, associadas a Satã e herdeiras de todo o temor cristão que é associado ao demoníaco; o cristianismo manteve as mulheres ora como redentoras, ora como destruidoras ${ }^{51}$. Nós, dissidentes, somos o indefinido, as que possuem cucetas, paus e transam pelo ânus, o local dos demônios ${ }^{52}$, nosso centro vital. Somos esfinges sexuais, sadomasô bélicas, pós-pornô terroristas.

O corpo bixa copta e recria ficções do feminino e da sexualidade - da bruxa, da puta-, que são consideradas para o patriarcado como faces do pior dos instintos humanos até os dias de hoje ${ }^{53}$. Muitas das entidades criadas no filme são femininas, libertas e plenas de seus desejos. Nós, bixas, desde pequenas, queremos desmunhecar, rebolar e celebrar à feminalidade que nos flui naturalmente. Como já dito anteriormente em relação ao "estado entico performático", nossa presença cotidiana é tratada de forma austera usualmente e, quando essa mesma presença é ressaltada pela performance, é vista como ameaça ao hétero cis-tema, algo que vem duma política do desejo e da violência:

\footnotetext{
"A violência contra as mulheres, assim como contra corpos desobedientes de gênero e dissidentes sexuais em geral está enraizada numa política do desejo que opera aquém da lei (...) desejo de perpetuação desse sistema que garante o direito de gerir e performar a violência não apenas ao estado, mas também ao homem cisgênero" (MOMBAÇA, 2016, p.6).
}

Assim, nos apropriamos da carga moralizante e violenta que nos impõem e a devolvemos endiabradas, debochadas ao hétero ciste-ma, revendo suas estéticas e as ocupando com as nossas. Duas figuras emblemáticas que possuem essa resposta à violência como parte integrante de seus simbolismos são Nova-Hera e Dioneia. Nova- Hera foi uma personagem originalmente criada a partir de uma estética de super- heroínas de histórias em quadrinho. Seu nome é um jogo entre

\footnotetext{
${ }^{51}$ ROCHA, Carolina. O Sabá do Sertão: Feiticeiras, demônios e jesuítas no Piauí Colonial. Jundiaí: Paco Editorial, 2015. p.54.

${ }^{52}$ COSTA, Pêdra. Periódicus, Salvador, n.7, v.1, Revista de estudos indisciplinares em gêneros e sexualidades. Publicação periódica vinculada ao Grupo de Pesquisa CUS, UFBA. maio-out. 2017. p.453.

${ }^{53}$ FALEIROS, Fabiana. 0 pulso que cai e as tecnologias do toque. São Paulo: Ikrek edições, 2016. p.43.
} 
eras e heras ${ }^{54}$. Ela surge após o texto: "fluem de nossas pétalas o gozo não reprodutivo, temos cucetas, temos paus, temos clitóris prostáticos. Somos o devirflor, somos o devir mulheromem ${ }^{55}$ ". Após a aparição textual em grafismos, cuja fonte inspira-se em histórias em quadrinho de terror, desabrocha uma animação 3D de uma flor de pétalas azuis que logo transforma-se em uma flor narciso, em referência ao nome da própria atriz que protagoniza a personagem. A flor fica localizada na altura genital de Nova-Hera. A personagem está o tempo todo coberta de uma luz azul estridente, vestindo uma roupa rosada transparente e óculos inseticos brilhantes. Dirigi Giorgia para que incorporasse corporalmente uma performance de imaginário extraterrestre e que todo seu corpo replicasse movimentos de insetos, como o louva-deus por exemplo. Giorgia é modelo e artista, tendo uma consciência corporal para as câmeras que a intensificou como presença performática entica. Nova-Hera retira então de sua boca uma tesoura dourada, em referência às moiras, mais uma das figuras mitológicas de raízes ocidentais que subverto em hibridismos e atualizações. As moiras eram três velhas irmãs anciãs responsáveis pela vigília, manipulação e confecção do fio de vida de todos os entes (humanos e deuses) na mitologia grega, possuíam tesouras incumbidas de cortar os fios daquelxs que deveriam partir do plano físico. Nova-Hera foi batizada como “a que rege destinos”, baseada na atualização desse arquétipo grego em entidade dissidente.

No Passo II existe uma característica comum em todas as cenas que é o encontro entre duas ou mais entidades, seja de maneira explícita ou emblemática. NovaHera sai de cena para a aparição de Lyz Parayzo como Dioneia. Dioneia é outro nome dado às plantas carnívoras; uma personagem agressiva e cujo semblante se mantém firme, quase imutável, sua pele é verde dourado e seu vestido possuí

\footnotetext{
54 Hera Venenosa foi uma das referências para Nova-Hera, sendo uma personagem anti-heroíca criada por Robert Kanigher e Sheldon Moldoff em 1966 pela DC Comics. A outra referência direta foi a deusa Hera, que impera o Monte Olimpo ao lado de Zeus, sendo a divindade das mulheres, casamento, família e nascimento.

${ }^{55}$ Toda essa frase e a concepção dos devires dissidentes foi inspirada pela leitura do tópico "A vagina de adão" do capítulo "A industrialização dos sexos ou Money makes sex". PRECIADO, Paul B. Manifesto Contrassexual. São Paulo: n-1 edições. 2017. Pág.123 a 129.
} 
várias camadas de tecidos como organza e celofane, que simulam pétalas da planta-carnívora. A personagem foi escrita a partir da pesquisa da própria artista que trabalha com ações e objetos que questionam as instituições de arte, principalmente em referência à performance "Fato-Indumento"56. Lyz refere-se a si mesma "como um vírus que se reproduz e infesta o sistema. Sua arte é política no sentido de quebrar tabus e se apresentar como uma alternativa viável de arte sem amarras, sem concessões ao mercado e ao sistema."( QUEIROZ; MOSS. 2017. Pág.8). Dioneia começa sua aparição batendo em grades do que parece ser uma prisão com janela vermelha. Um encarceramento simbólico da entidade que quer se libertar. A câmera revela que seu rosto também é repleto de flores douradas e uma rede que cobre seus olhos, além de mais flores em seus cabelos. Ela então sobe por escadas metálicas e começa a despedaçar violentamente suas pétalas "carnívoras" e vai revelando seu corpo aos poucos, terminando em seu rosto.

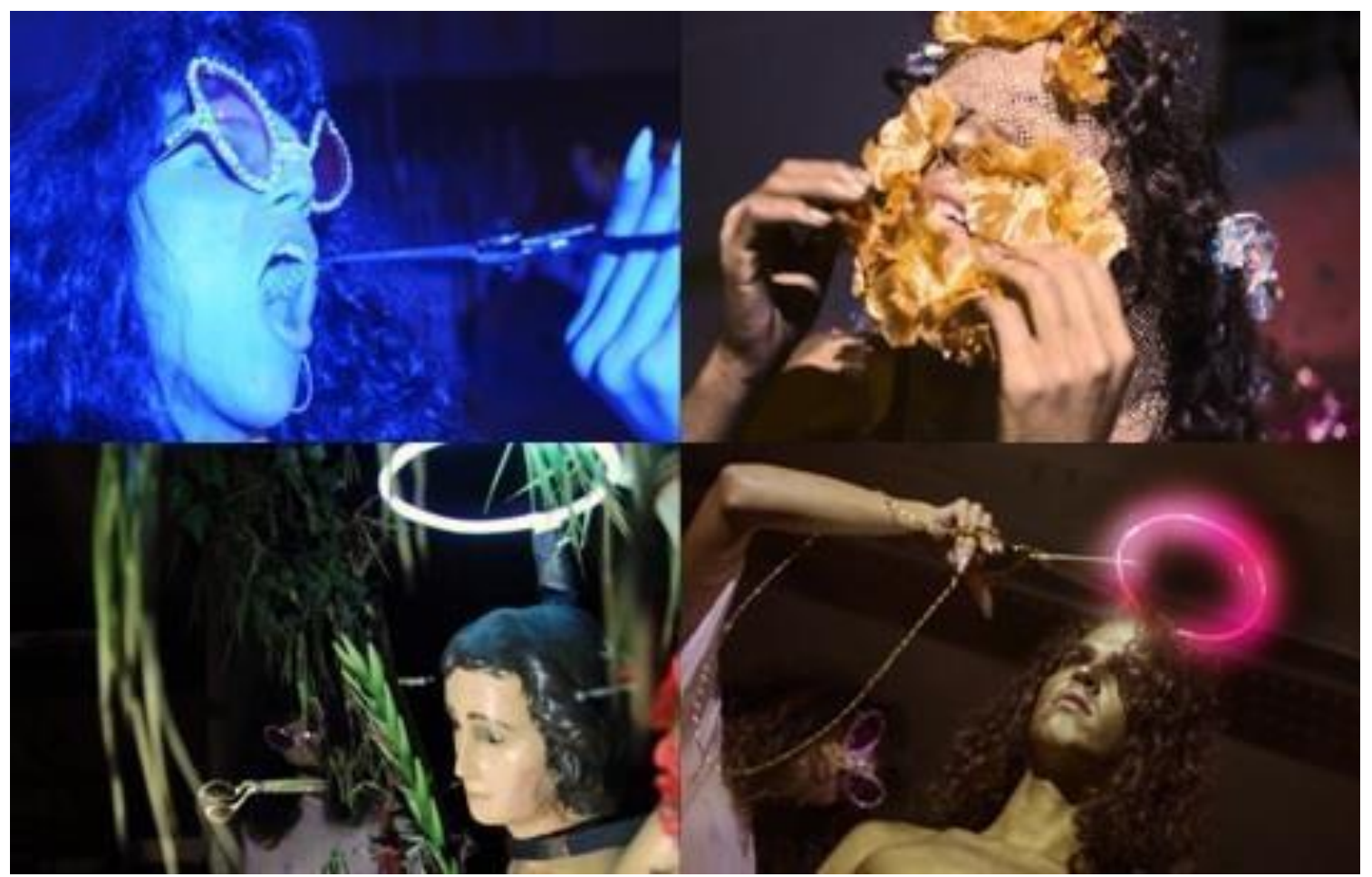

Imagem 4: Giorgia Narciso como Nova-Hera, a que rege destinos encontra com Dioneia, a plantacarnívora atroz, interpretada por Lyz Parayzo. Ascensão e Queda das Bixas. Direção Rodrigo D'Alcântara. 38'. 2018

\footnotetext{
56 https://cargocollective.com/lyzparayzo/Fato-Indumento
} 
A cena final é o encontro de Nova-Hera junta à imagem de porcelana de São Sebastião de aureola azul, como a luz que concebeu a Nova-Hera em sua aparição. O ângulo da câmera muda para o outro lado da face do Santo, aonde encontra-se Dioneia já totalmente nua e com uma auréola vermelha que é então cortada por Nova-Hera. Ambas entidades foram interpretadas por artistas trans tendo o simbolismo de serem flores desobedientes, uma alusão direta a suas não conformidades com as normas do hétero cis-tema. Nova-Hera, que é responsável pelos destinos, ao encontrar a planta carnívora atroz em seu estado primário, sem as pétalas, sem expectativas de gênero, a prepara para o seu destino final que é ser profanada como libertação.

A personagem de Andaluz é a aparição seguinte, sendo anunciada como "a que não sabem pronunciar o nome". Andaluz é uma figura não-binária que possuí influência da Drag Uhura Bqueer da artista que a interpreta, Rafael Bqueer. 0 vestido da entidade foi confeccionado baseado na peça monocromática vermelha usada pela cantora estadunidense Grace Jones durante sua turnê mundial Hurricane Tour, em 2009. O visual de inspiração usado por Jones é assinado pela estilista japonesa Eiko Ishioka. No contexto da performance houve também identificação com a entidade de matriz afro- brasileira umbandista chamada de Pomba Gira. Andaluz assim como a Pomba Gira tem na cor vermelha sua maior expressão e é uma mulher livre, sedutora e mensageira entre o plano espiritual e material. A cena originalmente seria uma dança de improviso realizada em diálogo a sons de sirenes de viaturas policiais. Porém, ao definirmos a locação da Fundição Progresso ${ }^{57}$ mudei o conceito da cena adaptando-a ao Palco São Sebastião, que é uma plataforma losangonal preta que lá se encontra. Nas extremidades do losango colocamos duas cruzes. Na primeira cruz, vermelha, começa a dança de Andaluz que é ligeira como o seu nome. A personagem retira um jogo de pisca-piscas amarelo de dentro de sua boca, conforme Nova-Hera retirou a tesoura de reger destinos. A entidade brinca com as luzes, que representa o fio de sua própria vida

\footnotetext{
${ }^{57}$ Centro de eventos culturais localizado no Rio de Janeiro que apoiou o filme abrindo as portas para algumas das gravações, incluindo as realizadas para as personagens Andaluz, Dioneia e Nova-Hera.
} 
e dança exasperada, até encerrar a cena sobre a cruz da outra ponta do palco, formada por outro jogo de pisca-piscas, dessa vez azul. Toda a cena acontece ao som da música que compus responsável por criar a tônica da personagem:

$$
\begin{gathered}
\text { “ela vai, veio nos ver } \\
\text { salto alto trinca pé } \\
\text { bela força de mulher } \\
\text { seu corpo tá a escutar } \\
\text { tudo que nos outros vê falando }
\end{gathered}
$$

$$
\begin{gathered}
\text { mas não vai se importar } \\
\text { seu olhar tá além mar } \\
\text { quer se manter bem de pé } \\
\text { não ter com que se preocupar } \\
\text { e quando ocupar o mar } \\
\text { ó povo venha lhe clamar } \\
\text { chora ao ver a verdadeira sombra } \\
\text { chora ao ver a verdadeira sombra } \\
\text { sobre seus olhos a noite alta } \\
\text { rodopia ao se ver em falta } \\
\text { cospem em seu corpo três dos homens } \\
\text { faz acontecer mil motins } \\
\text { traz tudo a tona os deixa imóveis } \\
\text { trás sua voz força maior que touros } \\
\text { e a luz permanece em seu toque } \\
\text { pó chora ao ver a verdadeira sombra } \\
\text { daqueles que não sabem } \\
\text { pronunciar seu nome.” }
\end{gathered}
$$




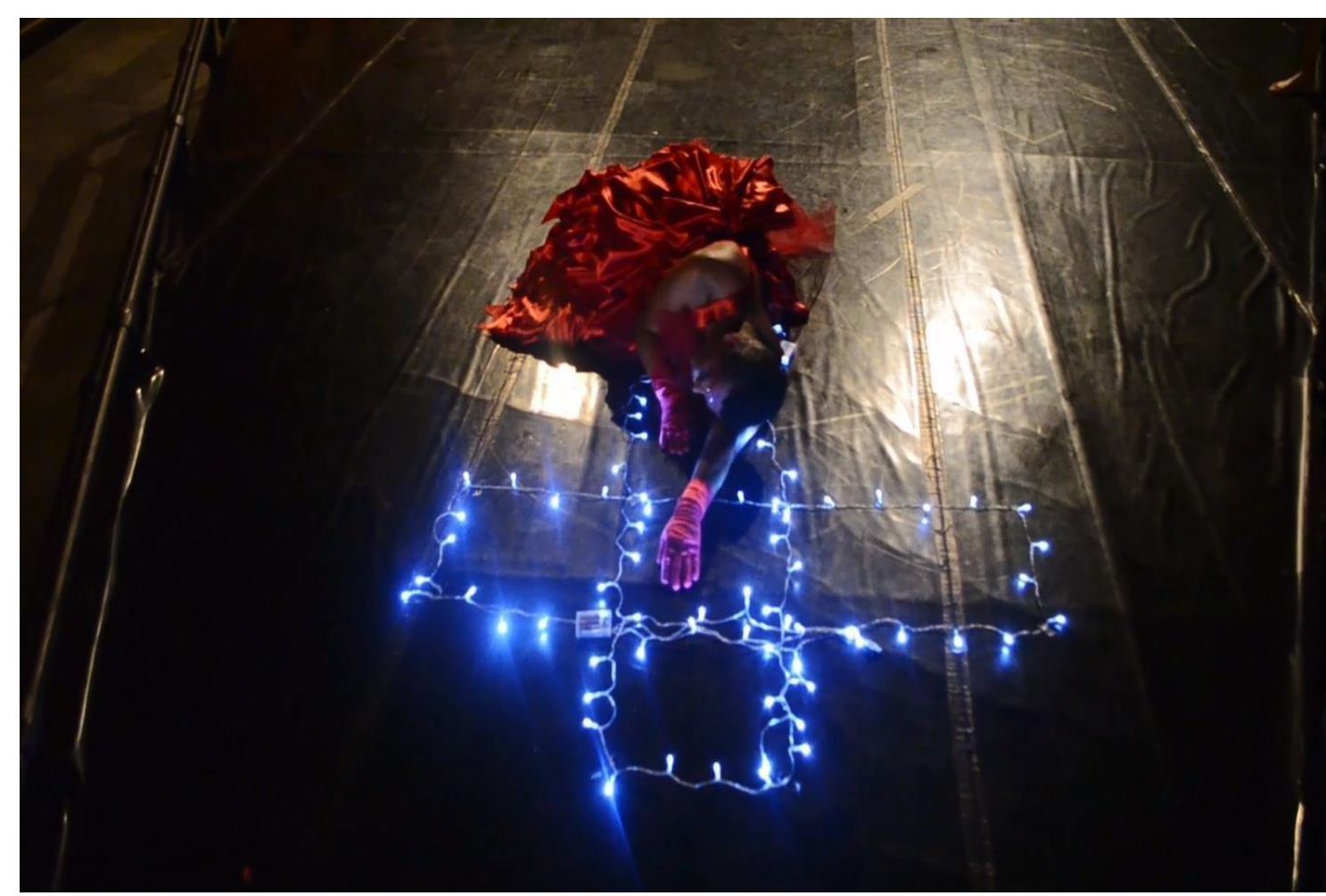

Imagem 5: Rafael/Uhura Bqueer na cena final de Andaluz, a que não sabem pronunciar o nome. Ascensão e Queda das Bixas. Direção Rodrigo D’Alcântara. 38'. 2018

A música e sua letra contextualizam a entidade que não sabem pronunciar o nome, simbolizando a identidade de gênero inominável e os revezes que sente na sociedade. É uma das cenas de teor mais próximo ao de video-clipes pela interação direta das letras e melodia com os passos de Bqueer. Durante todo o filme Ascensão e Queda das Bixas, como já dito anteriormente, a trama mostra em cada cena um universo próprio das entidades ali interpretadas. Há na obra poucos momentos de voz direta, as personagens performam para as câmeras e em quase todos os casos a estratégia utilizada para atingir a composição pretendida foi realizada pelo trabalho de diálogo junto axs artistas de pós- produção. Além da coloração feita pela fotógrafa e performer Maíra Barillo, a montagem e os efeitos especiais executados pelo artista visual Guerreiro do Divino Amor estão presentes no filme como conversa direta também a sua pesquisa artística, que explora as "Superficções", forças ocultas que interferem na construção do território e do 
imaginário coletivo ${ }^{58}$.

Finalmente, a video-arte como meio artístico desde seus primórdios provou ser exatamente um canal de experimentação crítica e de diálogo com as urgências criativas pretendidas para a época. Acredito que o audiovisual associado a uma origem vídeo- artística age como um grande catalisador para que se expresse os anseios que me cercam como bixa latina (e o de outros grupos dissidentes), sendo uma plataforma de fusão para os diversos interesses e estéticas que circundam a pesquisa artística. Em Ascensão e Queda do Bixas foram consideradas técnicas como instalação, performance, arte sonora, grafismos, etc. Acredito que há um potencial transformador desse tipo de audiovisual video-artístico quando seus interesses estéticos estão associados ao protagonismo dissidente e aos códigos que são subvertidos por esse protagonismo; o que pode desencadear em um registro histórico de resistência. Propor peças audiovisuais dissidentes me leva a pensar num legado de nós minorias a ser perpetuado, gerando uma possibilidade de criação centrada nas próprias ficções que contemplem as nossas existências; tanto na atualização de conceitos acadêmicos como na representação simbólica de nossas práticas criativas e vidas em si.

58 http://artcontexto.com.br/portfolio/biografia-14-guerreiro-do-divino-amor/ 


\section{Bibliografia}

CACERES, Imayna; MESQUITA, Sunanda; UTIKAL, Sophie (org.). Anti*colonial Fantasies. Zaglossus. Vienna, 2017

CÔSTA, Pêdra. Periódicus, Salvador, n.7, v.1, Revista de estudos indisciplinares em gêneros e sexualidades. Publicação periódica vinculada ao Grupo de Pesquisa CUS, UFBA. maio-out. 2017.

CÔSTA, Pedra. The Kuir Sauvage. concinnitas | ano 17, volume 01, número 28, setembro de 2016

CRARY, Jonathan. Géricault, o Panorama e os Espaços de Realidade no início do Século XIX. Tradução: Joana Negri. Revista ECO-Pós, Transformações do Visual e do Visível, V.17, N.2, Rio de Janeiro: 2014.

D’ALCÂNTARA, Rodrigo. “O desejo por trás da queda: Ficções e ritos do corpo bixa”. UFRJ: Rio de Janeiro. 2018

DERRIDA, Jacques. Memórias de Cego: 0 auto-retrato e outras ruínas. Tradução: Fernanda Bernardo. Lisboa: Fundação Calouste Gulbenkian, 2010

FABIÃO, Eleonora. Programa performativo: o corpo-em-experiência. Unicamp. Revista do Lume. n.4, dez. 2013.

FALEIROS, Fabiana. O pulso que cai e as tecnologias do toque. São Paulo: Ikrek edições, 2016.

MOMBAÇA, Jota. Rumo a uma redistribuição desobediente de gênero e anticolonial da violência! Fundação Bienal de São Paulo, 2016.

MONDZAIN, Marie-José. Sideração. Rio de Janeiro: Zazie edições, 2016.

PRECIADO, Paul Beatriz. Multidões Queer: notas para uma política dos “anormais". v.19, n.1. Florianópolis: Revista Estudos Feministas, 2011.

PRECIADO, Paul B. Manifesto Contrassexual. São Paulo: n-1 edições. 2017.

QUEIROZ, Tania; MOSS, Angela. "Lyz Parayzo: Artista do Fim do Mundo". eRevista Performatus, Inhumas, ano 5, n. 17, jan. 2017. ISSN: 2316-8102.

ROCHA, Carolina. O Sabá do Sertão: Feiticeiras, demônios e jesuítas no Piauí Colonial. Jundiaí: Paco Editorial, 2015.

RODRIGUES, Graziela; TURTELLI, Larissa. Umbanda e método BailarinoPesquisador-Intérprete (BPI): confluências.

STUART, Meg. Are we here yet? Les presses du reel. Paris:2011. 
Sites:

http://artcontexto.com.br/portfolio/biografia-14-guerreiro-do-divino-amor/

https://cargocollective.com/lyzparayzo/Fato-Indumento

https://cargocollective.com/rodrigodalcantara/Cromaqueer

https://en.wikipedia.org/wiki/Poison_Ivy_(character)

https://pt.wikipedia.org/wiki/Arauto

https://vimeo.com/273013515

https://vimeo.com/177651942

https://vimeo.com/202996853

Recebido em: 16/11/2018

Aprovado em: 18/11/2018 